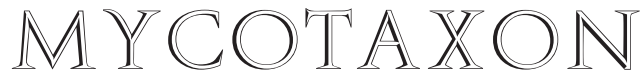

Volume 122, pp. 89-110

http://dx.doi.org/10.5248/122.89

October-December 2012

\title{
Lichenized and lichenicolous fungi new to \\ Babia Góra National Park (Poland, Western Carpathians)
}

\section{PaweŁ Czarnota ${ }^{1^{*}}$ \& Michą Węgrzyn ${ }^{2}$}

${ }^{1}$ Department of Agroecology and Landscape Architecture, Faculty of Biology and Agriculture, University of Rzeszów, Ćwiklińskiej 2, 35-601 Rzeszów, Poland

${ }^{2} Z d z i s ł a w$ Czeppe Department of Polar Research and Documentation, Institute of Botany,

Jagiellonian University, Kopernika 27, PL-31-501 Kraków, Poland

CORRESPONDENCE TO*: pawczarnota@poczta.onet.pl

Aвstract - 46 lichenized fungi and 1 lichenicolous fungus new to the Babia Góra Massif, a Polish and Slovak transborder mountain range, the highest in the flysch Western Carpathians, are presented here. Taxonomic and ecological remarks, as well as the distribution of some noteworthy taxa in other Carpathian ranges, are included. Helocarpon crassipes is reported in detail for the first time from the Western Beskidy Mts and Leptogium intermedium is rediscovered in the Polish Carpathians.

KEY wORDS - lichen diversity, lichen biota, lichens, Biosphere Reserve

\section{Introduction}

The Babia Góra Massif, the highest mountain range (1725 m a.s.l.) of the Western Beskidy Mts (part of the Western Carpathians), is located on the Polish-Slovak border. The main part of this transborder range belongs to Poland and is covered by the Biosphere Reserve of UNESCO MAB. Since the whole Babia Góra Massif has a unique and valuable natural character, an extension of the Reserve into Slovakia part is planned. The Protected Landscape Area 'Horna Orava' has covered the Slovak portion of the Massif since 1979, while the Polish side is almost entirely included within the Babia Góra National Park since 1954. Different nature conservation methods on both sides of the massif are nonetheless linked by compatible protection regimes.

The natural environment of the Carpathians was extensively exploited throughout the whole of the 18th and early 19th centuries, with mass deforestation and replacement by spruce monocultures on the degraded areas contributing to an impoverished epiphytic lichen biota. Moreover, excessive grazing of large cattle herds in the alpine and subalpine zones caused the destruction of terrestrial lichens, important components of alpine grasslands. 
The diversity of plant communities, forming vegetation zones from the lower forest zone to the alpine zone in the Babia Góra Massif, and especially relics of ancient upper spruce montane forests, continues to have a direct impact on the unique character of the lichen biota of the massif, which includes 350 species of both lichenized and lichenicolous fungi (Bielczyk 2004; Czarnota 2007; Kukwa et al. 2010).

The first reports on lichens of the Babia Góra Massif are by Stein (1872, 1873), whose data are repeatedly cited in the summary studies by Rehman (1879) and Boberski (1886). These contain information on some macrolichens (e.g. Usnea longissima, Sticta sylvatica) no longer recorded in this area, despite intensive lichenological studies were made by Suza (1951), Tobolewski (1966) and Nowak (1998). Other minor works referring mainly to the Atlas of the geographical distribution of lichens in Poland' and detailed history of all studies on lichens in the Babia Góra Massif are provided by Bielczyk (2004). In the first decade of this century, the area of Babia Góra NP has once more become a site of lichenological interest, with new reports of lichens from this region (Wegrzyn 2002; 2004). Except for the contributions by Lisická (1980) on two Umbilicaria species and Guttova (2001) on Microcalicium disseminatum, there are no additional published data from the Slovak side of Babia Góra Massif.

The known lichen diversity of the neighbouring lower flysch ranges of Western Beskidy Mts (Kiszka 1967; Nowak 1998; Czarnota 2010) suggests that the biodiversity is probably much greater in the Babia Góra Massif than published; indeed, our current lichenological results significantly extend the list by 47 taxa. However, we did not make a detailed exploration of all available lichen habitats in 2007-10 but focused on lichens occupying standing and fallen spruce 'dead wood' (including wind-throws) within the strictly protected area and investigated lichen diversity within 520 permanent plots regularly distributed throughout the park, including the highest alpine zone.

\section{Materials \& methods}

All collections except one were made in Babia Góra National Park. Lichens were identified by standard microscopy, with Lepraria, Cladonia and some sterile sorediate species checked through thin-layer chromatography (TLC) in solvent C according to Orange et al. (2001). Apothecial hand-made sections were mounted in water and anatomical structures were measured in $\mathrm{KOH}$. Spot test reactions of apothecial pigments were studied in $\mathrm{KOH}$ and $\mathrm{NaClO}$, and ascus types as well as medulla in IKI. Nomenclature follows MycoBank Fungal Databases (http://www.mycobank.org).

Examined materials and selected habitat notes are given for all taxa, while distributional, ecological and taxonomic notes are included for more noteworthy and rare species. The P. Czarnota collections are deposited in the Gorce National Park (GPN) herbarium while M. Węgrzyn collections are in the Jagiellonian University herbarium in Kraków (KRA).

Abbreviations: fs no. $=$ forest section number; ${ }^{*}=$ lichenicolous fungus. 


\section{The species}

\section{Absconditella delutula (Nyl.) Coppins \& H. Kilias}

Specimens examined: POLAND. Matopolska Province, SE slope of Kępa hill, fs no. $25 \mathrm{c}$ [ $49^{\circ} 34^{\prime} 29.4^{\prime \prime} \mathrm{N} 19^{\circ} 33^{\prime} 41.3^{\prime \prime} \mathrm{E}$ ], alt. $1360 \mathrm{~m}, 26.8 .2009$, leg. P. Czarnota 6339 (GPN); E slope of Sokolica hill, fs no. 17b [49 $35^{\prime} 15.1^{\prime \prime} \mathrm{N} 19^{\circ} 34^{\prime} 26.2^{\prime \prime} \mathrm{E}$ ], alt. $1140 \mathrm{~m}$, 9.6.2009, leg. P. Czarnota 6046 (GPN); NE slope of Sokolica hill fs no. 5 b close to 'Dolny Płaj' tourist track $\left[49^{\circ} 35^{\prime} 26.8^{\prime \prime} \mathrm{N} 19^{\circ} 34^{\prime} 14.9^{\prime \prime} \mathrm{E}\right]$, alt. $1040 \mathrm{~m}, 10.6 .2009$, leg. P. Czarnota 5991 (GPN); 'Górny Płaj' tourist track, near Mokry Staw lake, fs no. $18 \mathrm{~b}$ [49³5'25.18"N $19^{\circ} 33^{\prime} 57.2^{\prime \prime} \mathrm{E}$, alt. $1040 \mathrm{~m}, 10.11 .2010$, leg. M. Węgrzyn 4153 (KRA).

ECOLOGY \& DISTRIBUTION: Based on both the present study and previous investigations in other Polish ranges (Czarnota unpubl.), A. delutula seems not infrequent on sandstone pebbles over root systems of recent conifer wind-throws in montane forests. Sometimes it occurs on decaying wood (Pišút et al. 2007; Malíček et al. 2010).

This ephemeral species has been found several times in Poland (Czarnota \& Kukwa 2008a). The new sites extend its range in the Western Carpathians where it has previously been reported from both Polish (Gorce, Beskid Wyspowy Mts) and Czech (Moravskoslezké Beskydy) areas (Czarnota \& Kukwa 2008a; Malíček et al. 2010).

\section{Anisomeridium polypori (Ellis \& Everh.) M.E. Barr}

Specimen examined: POLAND, MaŁopolska Province, N of Markowe Szczawiny shelter house, fs no. $74 \mathrm{~b}\left[49^{\circ} 35^{\prime} 48.7^{\prime \prime} \mathrm{N} / 1^{\circ} 31^{\prime} 12.6^{\prime \prime} \mathrm{E}\right]$, alt. $880 \mathrm{~m}$, on decaying bark of roots of fallen Picea abies within Carpathian beech forest, 2.7.2009, leg. P. Czarnota $6120(\mathrm{GPN})$.

\section{Biatora chrysantha (Zahlbr.) Printzen}

Specimens examined: POlAND. Malopolska Province, N slope of massif, near Rybny Potok stream, fs no. 59a [49 $\left.36^{\prime} 53.2^{\prime \prime} \mathrm{N} / 19^{\circ} 32^{\prime} 15.3^{\prime \prime} \mathrm{E}\right]$, alt. $750 \mathrm{~m}$, on Alnus glutinosa bark, 4.8.2010, leg. M. Węgrzyn 4214 (KRA); NE slope of Sokolica, fs no. 17b [493' 15.0"N / 19³4'17.09" E], alt. 1200 m, on Sorbus aucuparia bark, 9.6.2009, leg. M. Węgrzyn 3169 (KRA).

ECOLOGY \& Distribution: B. chrysantha prefers old, natural forests, where it is found at the base of older trees and on over-growing bryophytes in high precipitation sites.

This species has been found in Poland several times in the Carpathians (Fałtynowicz 2003) and Western Pomerania (Kukwa \& Szymczyk 2006). Close to Babia Góra Massif it was reported only from Wielka Racza Mt. (Nowak 1998). In Europe its distribution is defined as suboceanic, since it is widely distributed in Scandinavia, Finland and the British Isles (Printzen \& Palice 1999), but it is also recorded in the central, mountainous part of Europe (e.g. Coppins et al. 1998, 2005; Kiszka \& Kościelniak 1998; Printzen \& Palice 1999; Pišút et al. 2007).

\section{Biatora helvola Körb. ex Hellb.}

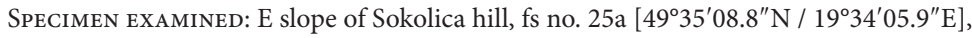
alt. $1280 \mathrm{~m}$, on Sorbus aucuparia bark within upper montane spruce forest, 9.6.2009, leg. P. Czarnota 6026 (GPN).

Biatora veteranorum Coppins \& Sérus.

Plate 1A

三 Catillaria alba Coppins \& Vězda

This species is almost exclusively cited in the literature as Catillaria alba (Palice 1999; Fletcher \& Coppins 2009), since it has only recently been 
transferred to Biatora (as B. veteranorum nom. nov., non B. alba Hepp) on the basis of its phylogenetic affinity to several other Biatora taxa (Sérusiaux et al. 2010). Verzda (1993) originally noted in the protologue that as this species does not belong to the genus Catillaria sensu stricto, the name Catillaria alba should be treated rather tentatively. Indeed, the 1-septate, ellipsoid ascospores, ascus tholus with a darker tube and non-amyloid conical ocular chamber, unpigmented apical caps of paraphyses, small bacilliform conidia, and the usual presence of short-stalked pycnidia suggest that the species may belong to another genus within, for example, Pilocarpaceae (Sérusiaux et al. 2010). Such pycnidia are almost unknown in Biatora except for B. ligni-mollis T. Sprib. \& Printzen, which forms rather sessile, globose, and never white pruinose pycnidia, whereas in $B$. veteranorum they are distinctly stalked, elongated, and almost white from distinct pruina. The 'core' pycnidial wall in B. veteranorum is white to pale beige, contrasting with the orange or slightly brown pycnidial pigmentation in B. ligni-mollis. Such pycnidial characters of major diagnostic importance for $B$. veteranorum, which is often found in only in the asexual stage. Stalked, pale pycnidia are also present in several Micarea species, e.g., M. doliiformis (Coppins \& P. James) Coppins \& Sérus., M. hedlundii Coppins, M. pycnidiophora Coppins \& P. James, M. stipitata Coppins \& P. James, and M. tomentosa Czarnota \& Coppins (Coppins 1983; Czarnota 2007; Sérusiaux et al. 2010), but there they are at most whitish tomentose and never pruinose. Moreover, all these species differ from $B$. veteranorum in their external thallus. All B. veteranorum specimens from the Babia Góra Massif have abundant apothecia, which are also white pruinose due to minute crystals confined to the epithecium.

Specimens examined: POLAND. MaŁopolska Province, N slope of Diablak Mt., fs no. 23a [49 $\left.34^{\prime} 55^{\prime \prime} \mathrm{N} / 19^{\circ} 31^{\prime} 10.7^{\prime \prime} \mathrm{E}\right]$, alt. $1270 \mathrm{~m}, 7.8 .2009$, leg. P. Czarnota 6265 (GPN); N slope of Sokolica hill, fs no. 7a [49 $\left.35^{\prime} 21.0^{\prime \prime} \mathrm{N} / 19^{\circ} 33^{\prime} 12.9^{\prime \prime} \mathrm{E}\right]$, alt. $1060 \mathrm{~m}$, 21.7.2009, leg. P. Czarnota 6225 (GPN); N slope of Diablak Mt., fs no. $10 \mathrm{~g}$ [49³4'57.3"N / 19³1'51.6"E], alt. $1180 \mathrm{~m}, 3.7 .2009$, leg. P. Czarnota 6172 (GPN). POLAND. Podkarpackie Province, Bieszczady Mts, Bieszczadzki National Park, Sianki forest district, fs no. 78i, on wood of a decaying Abies alba stump, mixed forest dominated by Picea abies, 19.6.2002, leg. P. Czarnota 2872 (GPN).

ECOLOGY \& DISTRIBUTION: B. veteranorum prefers slightly decayed wood of decorticated higher conifer snags within dense mixed and spruce montane forests, especially in lower zones, where it usually occupies shady niches.

This species has previously only been reported from Poland twice, both from the Polish Western Carpathians (Czarnota 2003, 2010; as Catillaria alba). The new records

PlATE. 1. Habits of several noteworthy species. A - Biatora veteranorum [Czarnota 6225 (GPN)]; B - Elixia flexella [Czarnota 6266 (GPN)]; C - Lecanora sarcopidoides [Czarnota 4199 (GPN)]; D - Lecanora subintricata [Czarnota 6062 (GPN); E - Leptogium intermedium [Węgrzyn 4151 (KRA)]; F - cross section of thallus of Leptogium intermedium [Węgrzyn 4151 (KRA)]; G - Lecidea leprarioides [Czarnota 6177 (GPN)]; H - Trapeliopsis glaucolepidea [Czarnota 6012 (GPN)]. 

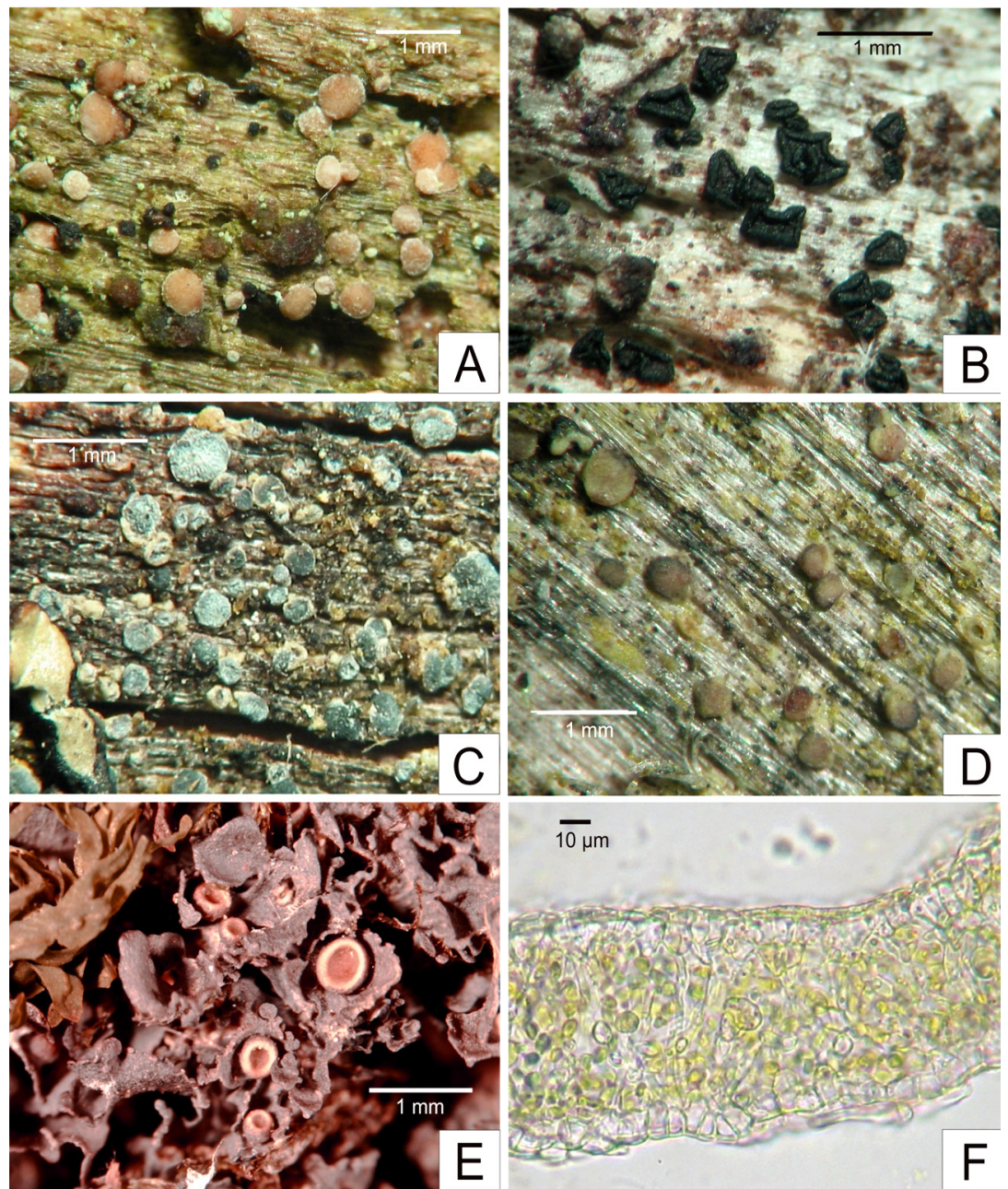

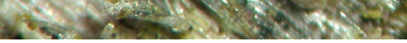

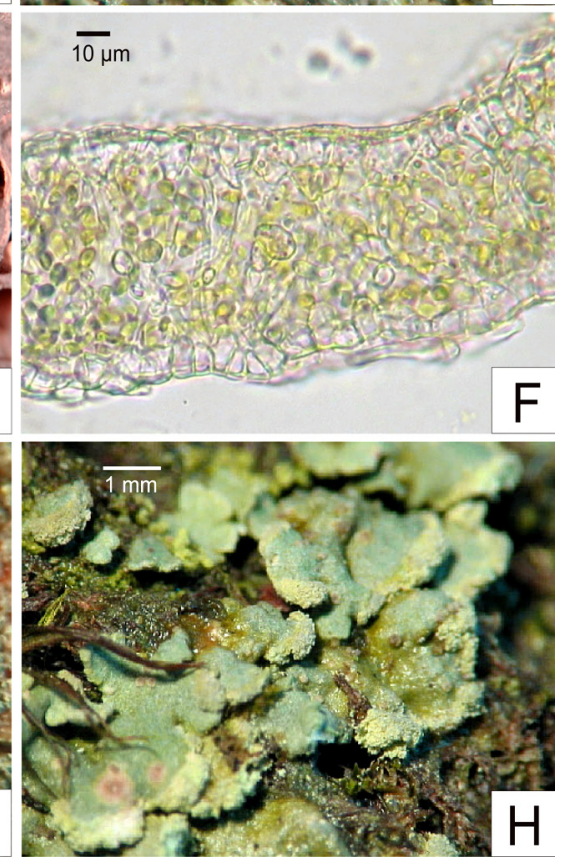

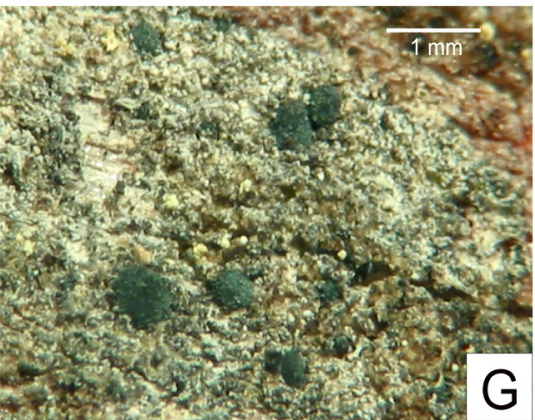


from Babia Góra Massif and Bieszczady Mts in Eastern Carpathians extend its range to the entire Polish part of this mountain range. B. veteranorum was also recorded in the Ukrainian Carpathians (Kondratyuk \& Coppins 2000).

\section{Calicium glaucellum Ach.}

Specimens examined: POLAND. MaŁopolska Province, N slope of Sokolica hill fs no. $7 \mathrm{a}\left[49^{\circ} 35^{\prime} 21.0^{\prime \prime} \mathrm{N} / 19^{\circ} 33^{\prime} 12.9^{\prime \prime} \mathrm{E}\right]$, alt. $1060 \mathrm{~m}, 21.7 .2009$, leg. P. Czarnota 6226 (GPN); ibid., [49³5'25.9"N / 19³3'12.2"E], alt. 1055 m, 21.7.2009, leg. P. Czarnota 6235

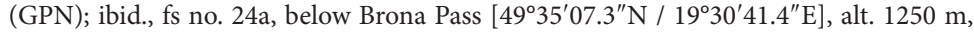
21.8.2009, leg. P. Czarnota 6311 (GPN); S slope of Kępa hill, fs no. 26h [49³4'07.8” N / $19^{\circ} 33^{\prime} 12.8^{\prime \prime} \mathrm{E}$ ], alt. $1290 \mathrm{~m}, 17.7 .2009$, leg. P. Czarnota 6078 (GPN); N slope of Diablak Mt., fs no. $10 \mathrm{~g}\left[49^{\circ} 34^{\prime} 58.2^{\prime \prime} \mathrm{N} / 19^{\circ} 31^{\prime} 45.7^{\prime \prime} \mathrm{E}\right]$, alt. $1180 \mathrm{~m}, 3.7 .2009$, leg. P. Czarnota 6140 (GPN); N slope of Babia Góra Massif, Czatoża Forest, fs no. 16a [49³5'42.0” N / $19^{\circ} 28^{\prime} 49.7^{\prime \prime} \mathrm{E}$ ], alt. $1200 \mathrm{~m}, 23.6 .2009$, leg. M. Węgrzyn 3792 (KRA).

Ecology \& Distribution: Similar to several other Calicium species, C. glaucellum is found on decaying wood of decorticated conifer trunks within different montane forests up to the timber line.

Although Tobolewski (1966) focused on species of the former Caliciaceae during his explorations of Babia Góra, he did not report this currently quite common epixylic lichenized fungus. However, in the Tobolewski key to Calicium (Nowak \& Tobolewski 1975), it was likely to be confused with C. abietinum Pers.

\section{Candelariella aurella (Hoffm.) Zahlbr.}

Specimen examined: POlAnd. Mazopolska Province, S slope of Diablak Mt., above the Rajsztag road, fs no. $99 \mathrm{~h}\left[49^{\circ} 33^{\prime} 45.1^{\prime \prime} \mathrm{N} / 19^{\circ} 43^{\prime} 46.8^{\prime \prime} \mathrm{E}\right]$, alt. $905 \mathrm{~m}$, on concrete of old building ruins, 11.6.2008, leg. M. Węgrzyn 4106 (KRA).

\section{Chaenothecopsis nigra Tibell}

Specimens examined: POLAND. Malopolska Province, N slope of Diablak Mt., fs no. $10 \mathrm{~g}\left[49^{\circ} 34^{\prime} 56.3^{\prime \prime} \mathrm{N} / 19^{\circ} 31^{\prime} 55.2^{\prime \prime} \mathrm{E}\right]$, alt. $1170 \mathrm{~m}, 3.7 .2009$, leg. P. Czarnota 6133 \& 6134 (GPN); ibid., [49³4'58.0"N / 19³1'52.1"E], alt. 1170 m, 3.7.2009, leg. P. Czarnota 6161 (GPN); below Brona Pass, fs no. 24a, [49 35'10.1"N / 19³0'47.1"E], alt. $1240 \mathrm{~m}$, 14.7.2009, leg. P. Czarnota 6188 (GPN).

ECOlOGY \& Distribution: Most specimens were collected on free-living algae Stichococcus in association with Chaenotheca stemonea on bark of dead spruces at trunk bases, but it was also found on Stichococcus over soil in root-system underhangs of fallen Picea abies; all collections were within upper montane spruce forest.

This species is often included in lists of lichenicolous fungi (e.g. Bielczyk 2003), but it is also sometimes lichenized (Giavarini \& Coppins 2009) as in this case. From Poland C. nigra has been reported only twice (Fałtynowicz 2003), including a record from Western Beskidy Mts (Bielczyk 2003) lacking details.

\section{Cladonia cenotea (Ach.) Schaer.}

Specimens examined: POLAND. Malopolska Province, S slope of Kępa hill, fs no. 26h [49³4'09.3"N / 19³3'03.2"E], alt. 1365 m, 17.7.2009, leg. P. Czarnota 6085 (GPN); $\mathrm{N}$ slope of the massif below Brona pass, fs no. $24 \mathrm{a}\left[49^{\circ} 35^{\prime} 01.0^{\prime \prime} \mathrm{N} / 19^{\circ} 30^{\prime} 33.5^{\prime \prime} \mathrm{E}\right]$, alt. $1330 \mathrm{~m}, 3.7 .2010$, leg. M. Węgrzyn 4005 (KRA).

Ecology \& Distribution: Common in the Polish Carpathians (Fałtynowicz 2003; Bielczyk 2003), this species is found on decaying wood of roots, soil, and plant debris in upper montane spruce forests. 


\section{Cladonia gracilis (L.) Willd.}

Specimens examined: POLAND. Malopolska Province, S slope of Gówniak hill, Wolarnia, fs no. $28 \mathrm{f}\left[49^{\circ} 34^{\prime} 14.3^{\prime \prime} \mathrm{N} / 19^{\circ} 32^{\prime} 13.0^{\prime \prime} \mathrm{E}\right]$, alt. $1575 \mathrm{~m}$, on soil, 10.7.2010, leg. M. Węgrzyn 4171 (KRA); close to Gówniak hill, fs no. 21f [ $49^{\circ} 34^{\prime} 32.18^{\prime \prime} \mathrm{N} / 19^{\circ} 32^{\prime} 27.24^{\prime \prime} \mathrm{E}$ ], alt. 1620 m, on soil, 27.8.2009, leg. M. Węgrzyn 3286 (KRA).

ECOLOGY \& DISTRIBUTION: This very common species in lowland Scots pine forests is also recorded in subalpine and alpine zones of mountain regions in Europe.

In the Tatra Mts alpine meadows are dominated by C. gracilis and C. amaurocraea (Flörke) Schaer. is rare (Osyczka \& Węgrzyn 2005), but the situation is reversed in the Babia Góra Massif (Węgrzyn unpubl.). Because C. amaurocraea and C. macroceras (Delise) Ahti are morphologically very similar to C. gracilis in this region, species determination requires more attention, including investigation of their secondary metabolites (Osyczka \& Węgrzyn 2005).

Cladonia grayi G. Merr. ex Sandst.

Specimen examined: POLAND. MaŁopolska Province, S of Sokolica hill, fs no. 25c [49 $34^{\prime} 58.3^{\prime \prime} \mathrm{N} / 19^{\circ} 33^{\prime} 48.3^{\prime \prime} \mathrm{E}$ ], alt. $1290 \mathrm{~m}$, on humus over root system of fallen Picea abies within upper montane spruce forest, 1.7.2009, leg. P. Czarnota 6114 (GPN).

\section{Cladonia norvegica Tønsberg \& Holien}

Specimen examined: POLAND. MaŁopolska Province, E slope of Sokolica hill, fs no. $25 \mathrm{a}\left[49^{\circ} 35^{\prime} 07.9^{\prime \prime} \mathrm{N} / 19^{\circ} 34^{\prime} 06.4^{\prime \prime} \mathrm{E}\right]$, alt. $1290 \mathrm{~m}$, on roots of fallen Picea abies within upper montane spruce forest, 9.6.2009, leg. P. Czarnota 6011 (GPN).

Distribution: The species is rare in Poland. Osyczka (2011) confirms its presence in the Tatra Mts, the Pieniny Mts, and the region of the Puszcza (Primeval) Augustowska and Puszcza Knyszyńska forests in northeast Poland.

\section{Cladonia ochrochlora Flörke}

The encountered specimen consists of several subulate and scyphose podetia. Generally, C. ochrochlora is characterized by areolate cortication with cortex especially well developed basally but sometimes extending upwards to near the apices or even inside narrow scyphi. The surface without cortex is covered by farinose to granular soredia (e.g. Ahti 2000; James 2009). This description can be applied to the specimen examined; however, some of the gathered podetia are almost totally areolate-corticate, partly richly squamulose, and produce only scattered granulose soredia. The specimen was fertile, with most of the podetia terminating in pale brown contiguous apothecia.

Specimen examined: POLAND. Malopolska Province, N foot of Diablak Mt., Stonów, fs no. $50 \mathrm{~b}\left[49^{\circ} 36^{\prime} 21.1^{\prime \prime} \mathrm{N} / 19^{\circ} 33^{\prime} 3.8^{\prime \prime} \mathrm{E}\right]$, alt. $770 \mathrm{~m}$, on decaying wood, 21.5.2010, leg. M. Węgrzyn 4008 (KRA).

ECOLOGY \& DISTRIBUTION: This species has previously been rather frequently reported from the Polish Carpathians (see Bielczyk 2003), but not from the Babia Góra Massif. The specimen was overgrowing decayed spruce wood.

Diploschistes muscorum (Scop.) R. Sant.

Specimen examined: POLAND. Malopolska Province, the main ridge of massif, close to Gówniak hill, fs no. 21f [ $\left.49^{\circ} 34^{\prime} 27.84^{\prime \prime} \mathrm{N} / 19^{\circ} 32^{\prime} 12.99^{\prime \prime} \mathrm{E}\right]$, alt. $1680 \mathrm{~m}$, on baserich soil between calcareous sandstones, 27.8.2009, leg. M. Węgrzyn 4215 (KRA). 
Elixia flexella (Ach.) Lumbsch

Specimens examined: POLAND. MaŁopolska Province, N slope of Diablak Mt., close to Suchy Stawek, fs no. $23 \mathrm{a}\left[49^{\circ} 34^{\prime} 55^{\prime \prime} \mathrm{N} / 19^{\circ} 31^{\prime} 10.7^{\prime \prime} \mathrm{E}\right]$, alt. $1270 \mathrm{~m}$, leg. P. Czarnota

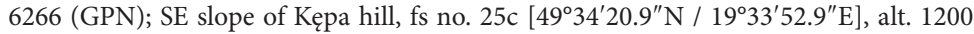
m, 17.7.2009, leg. P. Czarnota 6063 (GPN); below Brona Pass, fs no. 24a [49³5'09.3"N / $19^{\circ} 30^{\prime} 51.6^{\prime \prime} \mathrm{E}$ ], $1235 \mathrm{~m}, 14.7 .2009$, leg. P. Czarnota 6195 (GPN); N slope of Diablak Mt., fs no. $10 \mathrm{~g}\left[49^{\circ} 34^{\prime} 58.2^{\prime \prime} \mathrm{N} / 19^{\circ} 31^{\prime} 45.7^{\prime \prime} \mathrm{E}\right]$, alt. $1180 \mathrm{~m}, 3.7 .2009$, leg. P. Czarnota 6141 (GPN).

Ecology \& Distribution: Quite common on decaying wood of decorticated Picea abies trunks and fallen spruce roots within the upper montane spruce forest, E flexella is known elsewhere in the Polish Western Carpathians (Bielczyk 2003).

\section{${ }^{\star}$ Endococcus propinquus (Körb.) D. Hawksw.}

Specimens examined (both on sterile epilithic lichens): POLAND. Matopolska Province, SE slope of Kępa hill, fs no. 25c [49³4'21.8"N / 19³3'52.0"E], alt. 1210 m, 17.7.2009, leg. P. Czarnota 6072 (GPN); N slope of Sokolica hill, fs no. $18 \mathrm{~b}\left[49^{\circ} 35^{\prime} 26.5^{\prime \prime} \mathrm{N}\right.$ / 19³4'02.4"E], alt. 1050 m, 10.6.2009, leg. P. Czarnota 6049 (GPN).

Ecology \& Distribution: This lichenicolous fungus is probably common in the Babia Góra Massif; it grows on various epilithic lichens over sandstone rocks above the timberline but is also found within montane forests.

\section{Fuscidea pusilla Tønsberg}

Since Tønsberg (1992) described this species from Scandinavia, its distribution has markedly increased in Europe, despite its being found only in a sterile, usually overlooked or hardly distinguishable, form. The presence of divaricatic acid as the major diagnostic secondary substance appears sufficient for distinguishing F. pusilla from several other morphologically similar species: Ropalospora viridis (Tønsberg) Tønsberg, Mycoblastus fucatus (Stirt.) Zahlbr., Fuscidea arboricola Coppins \& Tønsberg, and Buellia griseovirens (Turner \& Borrer ex Sm.) Almb. Ropalospora viridis, also sterile (except a few fertile reports; Tønsberg 1992), differs almost only in the presence of perlatolic acid and thus is not UV+ bluish-white (contrasting with F. pusilla, which contains divaricatic acid). The other three species, which also contain substances other than divaricatic acid, are easily detected in simple spot tests such as: $\mathrm{P}+$ ginger from fumarprotocetraric acid (M. fucatus and F. arboricola) and $\mathrm{K}+$ yellow turning to brownish-red and $\mathrm{P}+$ yellow to yellow-orange due to norstictic acid and substances of stictic acid complex in B. griseovirens. (Sometimes this $\mathrm{K}+$ reaction is almost invisible, as the norstictic acid concentration is below the detection limit, but then characteristic norstictic acid crystals can be observed in the slide preparation.) Lendemer (2011) provides excellent morphological and chemical comparisons of F. pusilla and R. viridis supported by colour figures.

Specimens examined (selected): POlAnd. Mazopolska Province, N slope of Diablak Mt., fs no. 22a [49 $\left.34^{\prime} 51.3^{\prime \prime} \mathrm{N} / 19^{\circ} 31^{\prime} 41.6^{\prime \prime} \mathrm{E}\right]$, alt. $1220 \mathrm{~m}, 7.8 .2009$, leg. P. 
Czarnota 6273 (GPN); E slope of Sokolica hill, fs no. 25a [49 35'07.9"N / 19³4'06.4"E], alt. 1290 m, 9.6.2009, leg. P. Czarnota 6010 (GPN); N slope of Diablak Mt., fs no. 10g [49 $\left.34^{\prime} 56.3^{\prime \prime} \mathrm{N} / 19^{\circ} 31^{\prime} 55.2^{\prime \prime} \mathrm{E}\right]$, alt. $1170 \mathrm{~m}, 3.7 .2009$, leg. P. Czarnota 6165 (GPN); E slope of Sokolica hill, fs no. 25a [49 $\left.35^{\prime} 08.2^{\prime \prime} \mathrm{N} / 19^{\circ} 34^{\prime} 07.4^{\prime \prime} \mathrm{E}\right]$, alt. $1280 \mathrm{~m}, 9.6 .2009$, leg. P. Czarnota 6201 (GPN); S slope of Kępa hill, fs no. 26h [49 $34^{\prime} 07.8^{\prime \prime} \mathrm{N} / 19^{\circ} 33^{\prime} 02.5^{\prime \prime} \mathrm{E}$ ], alt. $1365 \mathrm{~m}, 17.7 .2009$, leg. P. Czarnota 6214 (GPN); S of Sokolica hill, fs no. 25c [49 $35^{\prime} 01^{\prime \prime} \mathrm{N} / 19^{\circ} 33^{\prime} 47.6^{\prime \prime} \mathrm{E}$ ], alt. $1285 \mathrm{~m}, 1.7 .2009$, leg. P. Czarnota 6104 (GPN).

ECOLOGY \& DISTRIBUtion: Fuscidia pusilla has rarely been reported (normally as an epiphyte of deciduous trees) from the Polish and Ukrainian Carpathians (Bielczyk 2003; Kościelniak \& Kiszka 2003; Kondratyuk \& Coppins 2000), but in the Babia Góra Massif it is found as a common lichenized fungus on wood of dead decorticated spruces, snags and wind-throws.

The species has not been reported from the British Isles (Gilbert et al. 2009), whereas another divaricatic acid-producing sorediate Fuscidia, F. lightfootii (Sm.) Coppins \& P. James, is well known there. An assumption that both species may represent the same taxon and that F. pusilla is only a morph of F. lightfootii (Gilbert et al. 2009) has no molecular support. A mtSSU rDNA phylogeny of Fuscideaceae shows that the two species are not closely related (Bylin et al. 2007).

\section{Helocarpon crassipes Th. Fr.}

$\equiv$ Micarea crassipes (Th. Fr.) Coppins

Although molecular evidence suggests that $H$. crassipes is better treated in the separate genus Helocarpon Th. Fr. (Andersen \& Ekman 2005), it is still sometimes placed in Micarea Fr. (Coppins 2009). Indeed, the 'micareoid' photobiont, sparingly branched and anastomosed paraphyses, ascus structure, and mixture of Cinereorufa-green, Melaena-red, and Melaenida-red apothecial pigments (Meyer \& Printzen 2000) are phenotypic features found in some representatives of Micarea s. lat. (Coppins 1983). Micarea assimilata (Nyl.) Coppins in particular resembles $H$. crassipes in apothecial pigmentation, lack of secondary substances, and ecology. Both species are terricolous and have an arctic-alpine distribution (Coppins 1983), but they differ at least in the thallus and apothecial structure. Micarea assimilata forms thick, slightly convex areoles intermixed with cephalodia of its additional photobiont, Nostoc, while the $H$. crassipes thallus is composed of small, \pm globose, often coralloid areoles, with only a chlorococcoid photobiont. Young $H$. crassipes apothecia are marginate and constricted below hypothecium forming the distinct stalked base in contrast to the $M$. assimilata apothecia, which are never marginate and shortly stalked. Sterile forms of $H$. crassipes markedly resemble thalli of M. leprosula and M. submilliaria (Nyl.) Coppins and can grow together in alpine regions. However, both these species produce easily detected metabolites, namely gyrophoric acid and argopsin in $M$. leprosula ( $\mathrm{C}+\mathrm{red}, \mathrm{Pd}+$ ginger) and alectorialic acid in M. submilliaria ( $\mathrm{Pd}+$ yellow), and their thallus areoles are very fragile. Furthermore, both species differ from $H$. crassipes in their apothecial characters and spore septation (for more details see Czarnota 2007). Although Micarea appears not to be monophyletic (Andersen \& Ekman 2005) 
and phenetically not congeneric with Helocarpon, $H$. crassipes may represent Micarea in its classical sense by Coppins (1983), as many other representatives are morphologically distantly related to the 'core' Micarea prasina group. However, in the mtSSU sequence-based phylogenetic tree of Lecanorales, $H$. crassipes nests outside the former Micareaceae. We therefore prefer to retain the species in the separate genus Helocarpon.

Specimen examined: POLAND. Matopolska Province, Gówniak hill, by tourist track $\left[49^{\circ} 34^{\prime} 34^{\prime \prime} \mathrm{N} / 19^{\circ} 32^{\prime} 39^{\prime \prime} \mathrm{E}\right.$ ], alt. $1608 \mathrm{~m}$, on soil and decaying bryophytes, 11.11.2005, leg. P. Czarnota 4600 (GPN).

Ecology \& Distribution: This terricolous species occurs frequently in the alpine zone of the Tatra Mts (Bielczyk 2003; Czarnota unpubl.). Its presence in the Babia Góra Massif was noted by Czarnota (2007), but without locality details. Formerly Helocarpon crassipes was often recognized as Lecidea assimilata, under which name it is filed in some Polish herbaria (see Czarnota 2007).

\section{Lecanora chlarotera Nyl.}

Specimens exAmined (selected; each on a different deciduous tree): POLAND. Malopolska Province, S slope of Diablak Mt., near the Pl-Sk boundary [49 $33^{\prime} 23.47^{\prime \prime} \mathrm{N} / 19^{\circ} 31^{\prime} 47.59^{\prime \prime} \mathrm{E}$ ], alt. $1200 \mathrm{~m}, 14.5 .2008$, leg. M. Węgrzyn 3844 (KRA); Zawoja Markowa, fs no. $72 \mathrm{a}\left[49^{\circ} 36^{\prime} 14.2^{\prime \prime} \mathrm{N} / 19^{\circ} 31^{\prime} 13.0^{\prime \prime} \mathrm{E}\right]$, alt. $740 \mathrm{~m}, 11.7 .2010$, leg. M. Węgrzyn 4159 (KRA); N slope of massif, W of Sulowa Cyrhla glad, fs no. 71a [49 $35^{\prime} 49.4^{\prime \prime} \mathrm{N} / 19^{\circ} 31^{\prime} 36.9^{\prime \prime} \mathrm{E}$ ], alt. 870 m, 5.8.2010, leg. M. Węgrzyn 4160 (KRA).

\section{Lecanora expallens Ach.}

Specimens examined (selected): POlAnd. Mazopolska Province, N slope of Diablak Mt., fs no. 23a, close to Suchy Stawek [49 $\left.34^{\prime} 55^{\prime \prime} \mathrm{N} / 19^{\circ} 31^{\prime} 10.7^{\prime \prime} \mathrm{E}\right]$, alt. $1270 \mathrm{~m}$, 7.8.2009, leg. P. Czarnota 6268 (GPN); N slope of Sokolica hill, fs no. 7a [49³5'25.6"N / $19^{\circ} 33^{\prime} 06.9^{\prime \prime} \mathrm{E}$ ], alt. 1055 m, 25.8.2009, leg. P. Czarnota 6328 (GPN); S slope of Kępa hill, fs no. 26h [49 $\left.34^{\prime} 09.3^{\prime \prime} \mathrm{N} / 19^{\circ} 33^{\prime} 09.2^{\prime \prime} \mathrm{E}\right]$, alt. $1315 \mathrm{~m}, 17.7 .2009$, leg. P. Czarnota 6060 (GPN); ibid., [49³4'07.8"N / 19³3'12.8"E], alt. 1290 m, 17.7.2009, leg. P. Czarnota 6080 (GPN).

ECOLOGY \& Distribution: This usually sterile species is frequently reported from the Polish Carpathians (Bielczyk 2003) primarily as an epiphyte on deciduous trees. In Babia Góra Massif as in other higher ranges of the Western Carpathians, however, it frequently grows also on hard wood of decorticated dead spruces within upper montane forests (Czarnota unpubl.).

\section{Lecanora saligna (Schrad.) Zahlbr. var. saligna}

SPECIMENS EXAmined (on decaying wood, bark of snags and roots of fallen spruces): POLAND. Malopolska Province, N of Markowe Szczawiny shelter house, fs no. $74 \mathrm{~b}\left[49^{\circ} 35^{\prime} 48.7^{\prime \prime} \mathrm{N} / 19^{\circ} 31^{\prime} 12.6^{\prime \prime} \mathrm{E}\right]$, alt. $880 \mathrm{~m}, 2.7 .2009$, leg. P. Czarnota 6121 (GPN); below Brona Pass, fs no. 24a, [49³5'44.0"N / 19³1'10.3"E], alt. 940 m, 2.7.2009, leg. P. Czarnota 6131 (GPN); SE slope of Kępa hill near the Chodnik Parkowy trail, fs no. $27 \mathrm{f}$ [49 $\left.34^{\prime} 04.2^{\prime \prime} \mathrm{N} / 19^{\circ} 33^{\prime} 02.1^{\prime \prime} \mathrm{E}\right]$, alt. $1350 \mathrm{~m}, 28.5 .2009$, leg. M. Węgrzyn 3235 (KRA).

Lecanora sarcopidoides (A. Massal.) Hedl.

Plate 1C

Specimen examined: POLAND. Malopolska Province, below Brona Pass, fs no. $24 \mathrm{a}\left[49^{\circ} 35^{\prime} 10.8^{\prime \prime} \mathrm{N} / 19^{\circ} 30^{\prime} 45.7^{\prime \prime} \mathrm{E}\right.$ ], alt. $1240 \mathrm{~m}, 14.7 .2009$, leg. P. Czarnota 6194 (GPN). 
Lecanora subintricata (Nyl.) Th. Fr.

Plate 1D

This species usually develops an endoxylic thallus (Edwards et al. 2009), but occasionally a form with a thick, warted, slightly yellowish thallus is encountered as elsewhere in the Polish Carpathians (Czarnota 2010). It differs from other morphologically similar Lecanora species (e.g. L. sarcopidoides, L. saligna, endoxylic forms of L. conizaeoides Nyl. ex Cromb., L. albellula (Nyl.) Th. Fr.) in its chemistry (presence of only usnic acid) and smaller ascospores. Apothecia of L. subintricata are variously shaped and pigmented, and the presence of a more or less developed amphithecium depends on their ontogeny and ecological conditions. They are mostly concave, olive-grey and slightly yellowish-green at least in the margin, but sometimes apothecia of L. subintricata in similar circumstances are olive-brown to brown and often convex and immarginate, resembling those found in L. saligna var. saligna or some forms of L. phaeostigma (Körb.) Almb. Some apothecia can also be slightly pruinose, as in L. sarcopidoides, which, however, has larger ascospores and pseudoplacodiolic acid as the major substance. Lecanora conizaeoides is easily distinguished by $\mathrm{P}+$ ginger reaction (fumarprotocetraric acid) in its apothecial margin. The presence of brialmontin 1 as an additional minor secondary compound (Edwards et al. 2009) was not detected in the tested Polish L. subintricata specimens.

Specimens examined (selected): POland. MaŁopolska Province, N slope of Sokolica, fs no. $18 \mathrm{c}\left[49^{\circ} 35^{\prime} 15.3^{\prime \prime} \mathrm{N} / 19^{\circ} 33^{\prime} 49.7^{\prime \prime} \mathrm{E}\right]$, alt. $120 \mathrm{~m}, 26.8 .2009$, leg. P. Czarnota

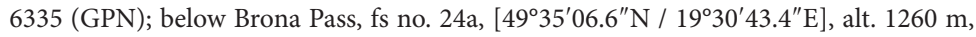
21.8.2009, leg. P. Czarnota 6284 (GPN); SE slope of Kępa hill, fs no. 25c [49³4'21.7"N / $19^{\circ} 33^{\prime} 51.9^{\prime \prime} \mathrm{E}$ ], alt. 1210 m, 17.7.2009, leg. P. Czarnota 6081 (GPN); S slope of Kępa hill, fs no. $26 \mathrm{~h}\left[49^{\circ} 34^{\prime} 07.7^{\prime \prime} \mathrm{N} / 19^{\circ} 33^{\prime} 01.9^{\prime \prime} \mathrm{E}\right]$, alt. $1365 \mathrm{~m}, 17.7 .2009$, leg. P. Czarnota 6067 (GPN).

ECOlogy \& Distribution: First modern records of L. subintricata for Poland were recently confirmed in the Gorce Mts (Czarnota 2010). Both there and in the Babia Gora Massif, L. subintricata is very common, mostly occupying decayed decorticated spruce wood, especially frequent in the upper spruce forests much destroyed by the activity of the bark beetle Ips typographus. In the Polish Western Carpathians, L. subintricata prefers hard wood exposed to the light and with L. expallens, L. phaeostigma, nonlichenized Mycocalicium subtile (Pers.) Szatala, and Strangospora moriformis appears to be one of the first common colonizers of this substrate.

\section{Lecidea leprarioides Tønsberg}

Plate $1 \mathrm{G}$

This species, which recently was reported from Gorce Mts as new for Poland (Czarnota 2010), was collected previously in other Carpathian regions as Lecidea turgidula Fr. or L. turgidula var. pulveracea Th. Fr. (Czarnota unpubl.). Indeed, L. leprarioides and L. turgidula often have almost identical apothecia, especially when the thallus of L. leprarioides is less developed and the L. turgidula apothecia are whitish to bluish pruinose. In such cases secondary compound analyses help differentiate the usually inconspicuously endosubstratal L. turgidula (which produces placodiolic acid) and distinctly sorediate L. leprarioides (which 
contains pseudoplacodiolic acid, rarely present in other lichens; Tønsberg 1992). Similar sorediate thalli, often found in similar habitats in the Carpathians, may also form in L. nylanderi (Anzi) Th. Fr. and diminutive examples of Ochrolechia microstictoides Räsänen. However, both species are usually sterile, in contrast to the usually fertile L. leprarioides, which is easily distinguished by its immarginate, convex, bluish-grey apothecia immersed within sorediate patches. All species differ markedly in their chemistry: L. nylanderi contains divaricatic acid and O. microstictoides variolaric and lichesterinic acids. Furthermore, their soredia are thicker and more granular, and thus their thalli are less farinose than the thallus of L. leprarioides. Another similar, usually sterile, sorediate epiphyte growing on acidic bark, which also sometimes serves as substrate for L. leprarioides, is Cliostomum leprosum (Räsänen) Holien \& Tønsberg. This species is, however, rare (reported mainly from N Europe; Golubkov \& Kukwa 2006) and its major compounds are atranorin and caperatic acid (Tønsberg 1992). For an excellent description of $L$. leprarioides and similarities to other morphologically related taxa, see also Tønsberg (1992) and Aptroot et al. (2009).

Specimens examined (selected): POLAND. MaŁopolska Province, N slope of Sokolica hill, fs no. $18 \mathrm{c}\left[49^{\circ} 35^{\prime} 13.7^{\prime \prime} \mathrm{N} / 19^{\circ} 33^{\prime} 48.3^{\prime \prime} \mathrm{E}\right]$, alt. $1200 \mathrm{~m}, 26.8 .2009$, leg. P. Czarnota 6302 (GPN); N slope of Diablak Mt., fs no. 21b [49³5'04.6"N / 19³2'15.3"E], alt. $1160 \mathrm{~m}, 3.7 .2009$, leg. P. Czarnota 6156 (GPN); below Brona Pass, fs no. 24a [49 $\left.35^{\prime} 10.2^{\prime \prime} \mathrm{N} / 19^{\circ} 30^{\prime} 50.4^{\prime \prime} \mathrm{E}\right]$, alt. $1230 \mathrm{~m}, 14.7 .2009$, leg. P. Czarnota 6177 (GPN); SE slope of Sokolica hill near the Chodnik Parkowy trail, fs no. $25 \mathrm{c}\left[49^{\circ} 34^{\prime} 44.0^{\prime \prime} \mathrm{N} /\right.$ $19^{\circ} 33^{\prime} 51.5^{\prime \prime} \mathrm{E}$ ], alt. $1380 \mathrm{~m}, 24.5 .2009$, leg. M. Węgrzyn 3823 (KRA); ibid., [49³4'51.7"N / 19³4'06.5"E], alt. 1300 m, 24.5.2009, leg. M. Węgrzyn 4152 (KRA).

ECOLOGY \& DISTRIBUTION: Lecidea leprarioides is a common lichenized fungus usually found on decayed wood of conifer snags, but sometimes it also grows directly on bark of spruces, more particularly within destroyed parts of upper montane spruce forests, similar to Lecanora subintricata.

\section{Lepraria eburnea J.R. Laundon}

Specimens examined (selected): POLAND. Malopolska Province, $N$ slope of Sokolica hill, fs no. $18 \mathrm{c}\left[49^{\circ} 35^{\prime} 13.7^{\prime \prime} \mathrm{N} / 1^{\circ} 33^{\prime} 48.5^{\prime \prime} \mathrm{E}\right]$, alt. $1200 \mathrm{~m}, 26.8 .2009$, leg. P. Czarnota 6349 (GPN); ibid., fs no. 6d [49 $\left.35^{\prime} 34.6^{\prime \prime} \mathrm{N} / 19^{\circ} 33^{\prime} 34.5^{\prime \prime} \mathrm{E}\right]$, alt. $990 \mathrm{~m}$, 25.8.2009, leg. P. Czarnota 6319 (GPN); E slope of Kępa hill, fs no. 25c [49³4'21.8'N / $19^{\circ} 33^{\prime} 52.0^{\prime \prime} \mathrm{E}$ ], alt. $1210 \mathrm{~m}, 17.7 .2009$, leg. P. Czarnota 6073 (GPN).

ECOLOGY \& DistRibution: On tree bark, decaying wood, and sandstone rocks in the lower and upper zones of Babia Góra Massif.

\section{Lepraria jackii Tønsberg}

This species is differentiated from other Lepraria species by an almost mealy thallus that is shared only by $L$. toensbergiana, from which it differs only chemically (Bayerová et al. 2005).

Specimens examined (selected): POlAnd. Matopolska Province, N slope of Diablak Mt., fs no. 22a [49 $\left.34^{\prime} 51.3^{\prime \prime} \mathrm{N} / 1^{\circ} 31^{\prime} 41.6^{\prime \prime} \mathrm{E}\right]$, alt. $1220 \mathrm{~m}, 7.8 .2009$, leg. P. Czarnota 6272 (GPN); E slope of Sokolica hill, fs no. 25a [49³5'08.8"N / 19³4'05.9"E], 
alt. 1280 m, 9.6.2009, leg. P. Czarnota 6053 (GPN); ibid., fs no. $18 \mathrm{c}$ [ $49^{\circ} 35^{\prime} 7.4^{\prime \prime} \mathrm{N} /$ $19^{\circ} 33^{\prime} 52.5^{\prime \prime} \mathrm{E}$ ], alt. $1350 \mathrm{~m}, 6.6 .2009$, leg. M. Węgrzyn 3261 (KRA); SE slope of Kępa

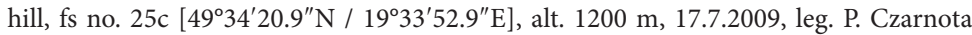
6064 (GPN); N slope of massif, below Dolny Płaj forest road, fs no. 57g [49³5'39.3" N / $19^{\circ} 32^{\prime} 51.6^{\prime \prime} \mathrm{E}$ ], alt. $900 \mathrm{~m}, 8.5 .2010$, leg. M. Węgrzyn 4146 (KRA).

ECOlOGY \& Distribution: This anamorphic lichenized fungus seems to be the most common Lepraria in the Western Carpathians. In addition to the Babia Góra Massif, many sites occur in the Gorce Mts (Czarnota \& Kukwa 2001), Beskid Sądecki Mts (Kukwa \& Śliwa 2005), and Tatra Mts (Kukwa 2004) where it usually grows on conifer bark, decaying stumps and snags, and roots of fallen trees.

\section{Lepraria rigidula (B. de Lesd.) Tønsberg}

Specimen examined: POLAND. MaŁopolska Province, N slope Diablak Mt., Sulowa Cyrhla glade $\left[49^{\circ} 36^{\prime} 04.9^{\prime \prime} \mathrm{N} / 19^{\circ} 32^{\prime} 14.4^{\prime \prime} \mathrm{E}\right.$ ], alt. $840 \mathrm{~m}$, on bark of Salix sp., 3.5.2010, leg. M. Węgrzyn 4156 (KRA).

Ecology \& Distribution: Although rather common in Poland (Kukwa 2006), L. rigidula has been thus far recorded only from one locality in the Babia Góra Massif. It may be more frequent here, especially on the bark of solitary or roadside deciduous trees at foot of the massif or in old orchards, as data suggest from other West Carpathian ranges (e.g. Kukwa \& Śliwa 2005).

\section{Leptogium intermedium (Arnold) Arnold}

Plate 1E, $\mathrm{F}$

This cyanolichen from the study area has a small thallus composed of numerous spreading squamules up to $3 \mathrm{~mm}$ in width, but most do not exceed $1.5 \mathrm{~mm}$. Vertical sections of the thallus are distinctly heteromerous, consisting of dense single-layered zones of large $(5-10 \mu \mathrm{m})$ cells in the upper and lower cortex surrounding loosely interwoven fungal hyphae in the medulla. Individual lobe margins are sometimes deeply cut. Their upper surface is unwrinkled and brownish-grey when dry. Concave apothecia are very numerous, $\leq 1.5 \mathrm{~mm}$ diam.; thalline margin distinct, beige, paler than the brownish disc.

L. intermedium mostly resembles diminutive specimens of L. gelatinosum (With.) J.R. Laundon, which, however, has larger lobes distinctly wrinkled at the upper surface and more brownish apothecial discs (Jørgensen 1994).

The material presented above differs slightly from the species description by Jørgensen (1994) and Gilbert \& Jørgensen (2009) in the size of squamules and apothecia, which are larger here. Furthermore, in the Polish specimen the upper thallus surface is rather smooth, in contrast to the weakly wrinkled lobes given as a diagnostic feature for L. intermedium.

Specimen examined: POlAND. Malopolska Province, N slope of massif, Czatoża Forest, fs no. $16 \mathrm{a}\left[49^{\circ} 35^{\prime} 44.7^{\prime \prime} \mathrm{N} / 19^{\circ} 28^{\prime} 57.2^{\prime \prime} \mathrm{E}\right]$, alt. $900 \mathrm{~m}$, on the base of a mossy old beech within ancient Carpathian beech forest, 29.10.2008, leg. M. Węgrzyn 4151 (KRA).

ECOlOgY \& Distribution: This species is widespread in Europe (Jørgensen 1994; Gilbert \& Jørgensen 2009) but has been reported only twice in Poland from the Gorce Mts in the Carpathians (Czarnota 1997) and the Góry Kaczawskie Mts in the Sudetes 
(Kossowska 2008), where it was found on a clayey soil overlying calcareous sandstone and on mossy rocks in deeply shaded places (Czarnota 1997; Kossowska 2008). In the Babia Góra Massif, L. intermedium occurs on the base of a mossy old beech in the best conserved fragment of an ancient Carpathian beech forest in this massif. Such a substrate is rarely reported elsewhere.

Although L. intermedium was discovered in the Polish Carpathians no more than 20 years ago (Czarnota 1997), reports from the Gorce Mts should be regarded as historical. The 1997 flood completely destroyed all known L. intermedium sites in localities that region. Its new Babia Góra Massif locality may be the only site left in the Polish Carpathians.

\section{Micarea byssacea (Th. Fr.) Czarnota, Guz.-Krzemiń. \& Coppins}

Specimen examined: POLAND. Makopolska Province, N slope of Sokolica hill, fs no. $18 \mathrm{~b}\left[49^{\circ} 35^{\prime} 21.5^{\prime \prime} \mathrm{N} / 19^{\circ} 33^{\prime} 39.1^{\prime \prime} \mathrm{E}\right]$, alt. $1120 \mathrm{~m}$, on decaying wood of decorticated Picea abies within a montane spruce-fir forest, 10.6.2009, leg. P. Czarnota 6005 (GPN).

ECOLOGY \& DISTRIBUTION: Recently segregated from the Micarea micrococca complex, this species is characterized in detail by Czarnota \& Guzow-Krzemińska (2010). It is poorly known under the name $M$. byssacea, but is probably a more common epixylic or epiphytic lichenized fungus in lowland forests; in the Western Carpathians it is widespread, but uncommon (Czarnota unpubl.).

\section{Micarea leprosula (Th. Fr.) Coppins \& A. Fletcher}

Specimen examined: POland. Małopolska Province, Gówniak hill, by tourist track [ $49^{\circ} 34^{\prime} 34^{\prime \prime} \mathrm{N} / 19^{\circ} 32^{\prime} 39^{\prime \prime} \mathrm{E}$ ], alt. $1608 \mathrm{~m}$, on soil, decaying bryophytes, plant debris and terricolous lichens in alpine zone, 11.11.2005, leg. P. Czarnota 4598 (GPN).

ECOLOGY \& DISTRIBUTION: This terricolous alpine species was reported several times from the Polish Western Beskidy Mts, but its large population is located in the neighbouring Tatra Mts (Czarnota 2007). For taxonomic notes see also under Helocarpon crassipes.

\section{Micarea lithinella (Nyl.) Hedl.}

Specimens exAmined (selected; all on sandstone shaded pebbles): POLAND. MaŁopolska Province, SE slope of Kępa hill, fs no. 25c [49³4'29.6"N / 19³3'40.4"E], alt. 1360 m, 26.8.2009, leg. P. Czarnota 6351 (GPN); SE slope of Sokolica, fs no. 25c [49 $34^{\prime} 51.7^{\prime \prime} \mathrm{N} / 19^{\circ} 34^{\prime} 06.5^{\prime \prime} \mathrm{E}$ ], alt. $1300 \mathrm{~m}, 24.5 .2009$, leg. M. Węgrzyn 3170 (KRA); N slope of Sokolica hill, fs no. $18 \mathrm{c}\left[49^{\circ} 35^{\prime} 16.0^{\prime \prime} \mathrm{N} / 19^{\circ} 33^{\prime} 54.0^{\prime \prime} \mathrm{E}\right]$, alt. $1200 \mathrm{~m}, 6.6 .2009$, leg. M. Węgrzyn 4155 (KRA); N slope Diablak Mt., W of Sulowa Cyrhla, fs no. 70c [49 35'56.7"N / 19³1'35.4"E], alt. 830 m, 5.8.2010, leg. M. Węgrzyn 4158 (KRA).

ECOlOgY \& Distribution: This epilithic species is a common early colonizer of sandstone pebbles over root systems of wind-throws within montane forests, as indicated recent studies in other ranges of the Western Carpathians (Czarnota unpubl.).

\section{Micarea nowakii Czarnota \& Coppins}

Specimens examined: POLAND. Malopolska Province, below Brona Pass, fs no. 24a [49 $\left.35^{\prime} 09.6^{\prime \prime} \mathrm{N} / 19^{\circ} 30^{\prime} 49.1^{\prime \prime} \mathrm{E}\right]$, alt. $1235 \mathrm{~m}, 14.7 .2009$, leg. P. Czarnota 6212 (GPN); $\mathrm{N}$ slope of Sokolica, fs no. $18 \mathrm{c}\left[49^{\circ} 35^{\prime} 15.0^{\prime \prime} \mathrm{N} / 19^{\circ} 33^{\prime} 49.7^{\prime \prime} \mathrm{E}\right]$, alt. $1200 \mathrm{~m}, 26.8 .2009$, leg. P. Czarnota 6307 (GPN); E slope of Sokolica hill, fs no. 25a [49 $35^{\prime} 08.8^{\prime \prime} \mathrm{N} /$ $19^{\circ} 34^{\prime} 05.9^{\prime \prime} \mathrm{E}$ ], alt. 1280 m, 9.6.2009, leg. P. Czarnota 6023 (GPN); S slope of Kępa hill, fs no. $26 \mathrm{~h}\left[49^{\circ} 34^{\prime} 09.3^{\prime \prime} \mathrm{N} / 19^{\circ} 33^{\prime} 03.2^{\prime \prime} \mathrm{E}\right]$, alt. $1365 \mathrm{~m}, 17.7 .2009$, leg. P. Czarnota 6086 (GPN). 
Ecology \& Distribution: This recently described species (Czarnota 2007), a member of the Micarea prasina group (Czarnota \& Guzow-Krzemińska 2010), appears to be an early colonizer of decorticated logs of spruce wind-throws in the upper montane zone of Babia Góra Massif. It prefers well-lit places, especially forest areas destroyed by the bark beetle Ips typographus. The present data extend the range of $M$. nowakii to other parts of Western Carpathians, being additional to its first discoveries in the Gorce Mts and Beskid Mały Mts (Czarnota 2007).

A realistic world distribution of $M$. nowakii is as yet unknown due to its phenetic similarity to $M$. denigrata, $M$. misella, and dark coloured morphotypes of $M$. prasina. It differs from $M$. denigrata by its usually simple and shorter ascospores and lack of gyrophoric acid, from M. misella by its wider conidia (similar to M. denigrata) and the presence of micareic acid, and from $M$. prasina by its usually numerous black, barrel-like and aggregated pycnidia, and lack of thallus composed of goniocysts. $M$. nowakii is also reported from Sweden (Svensson \& Westberg 2010).

\section{Peltigera leucophlebia (Nyl.) Gyeln.}

Specimen examined: POLAND. MaŁopolska Province, N slope of Diablak hill, fs no. $22 \mathrm{~m}\left[49^{\circ} 34^{\prime} 23.2^{\prime \prime} \mathrm{N} / 19^{\circ} 31^{\prime} 32.0^{\prime \prime} \mathrm{E}\right]$, alt. $1620 \mathrm{~m}$, on plant debris in Salix silesiaca community, 7.8.2009, leg. M. Węgrzyn 3198 (KRA).

Ecology \& Distribution: This arctic-boreal-alpine species is widespread in the northern hemisphere but is very rare in the Western Carpathians, except in the subalpine and alpine zones of the Tatra Mts (Lisická 2005). From other Polish parts of the Western Carpathians, it has only been reported on three occasions growing in lower forested mountain zones (Bielczyk 2003). In the Babia Góra Massif, P. leucophlebia occurs above timberline, where terricolous and mossy habitats are much more suitable for the species.

Physcia caesia (Hoffm.) Hampe ex Fürnr.

Specimen examined: POLAND. MaŁopolska Province, NW slope of Mała Babia Góra hill, Czarna Cyrhel glade [49 $35^{\prime} 50.0^{\prime \prime} \mathrm{N} / 19^{\circ} 29^{\prime} 8.8^{\prime \prime} \mathrm{E}$ ], alt. $880 \mathrm{~m}$, on concrete, 23.6.2009, leg. M. Węgrzyn 4253 (KRA).

Physcia tenella (Scop.) DC.

Specimen examined: POLAND. Malopolska Province, N slope of Diablak Mt., Sulowa Cyrhla glade [49 $36^{\prime} 04.9^{\prime \prime} \mathrm{N} / 19^{\circ} 32^{\prime} 14.4^{\prime \prime} \mathrm{E}$ ], alt. $840 \mathrm{~m}$, on bark of Salix sp., 3.5.2010, leg. M. Węgrzyn 4162 (KRA).

\section{Physconia grisea (Lam.) Poelt}

Specimen examined: POLAND. Malopolska Province, $\mathrm{N}$ foot of Diablak Mt., Zawoja Markowa, fs no. 72 d [ $49^{\circ} 36^{\prime} 29.8^{\prime \prime} \mathrm{N} / 19^{\circ} 31^{\prime} 03.5^{\prime \prime} \mathrm{E}$ ], alt. $740 \mathrm{~m}$, on bark of roadside Fraxinus excelsior, 14.5.2010, leg. M. Węgrzyn 4219 (KRA).

\section{Placynthiella oligotropha (J.R. Laundon) Coppins \& P. James}

Specimens examined: POlAnd. Matopolska Province, below Brona Pass, fs no. $24 \mathrm{a}\left[49^{\circ} 35^{\prime} 10.8^{\prime \prime} \mathrm{N} / 19^{\circ} 30^{\prime} 50.5^{\prime \prime} \mathrm{E}\right]$, alt. $1230 \mathrm{~m}, 14.7 .2009$, leg. P. Czarnota 6173 (GPN); ibid., [49 $35^{\prime} 10.1^{\prime \prime} \mathrm{N} / 19^{\circ} 30^{\prime} 47.1^{\prime \prime} \mathrm{E}$ ], alt. $1240 \mathrm{~m}, 14.7 .2009$, leg. P. Czarnota 6202 (GPN); N foot of Diablak Mt., Zawoja Markowa, fs no. 77a [49 36'13.8” N / $19^{\circ} 30^{\prime} 22.5^{\prime \prime} \mathrm{E}$ ], alt. 815 m, 6.8.2010, leg. M. Węgrzyn 4217 (KRA).

ECOLOGY \& DISTRIBUtion: In the Babia Góra Massif this terricolous species prefers well-lit soil over root systems of wind-throws, similar to those in other ranges of Western 
Carpathians (Czarnota unpubl.). In these habitats it is a frequent member of a pioneer lichen biota.

Porina chlorotica (Ach.) Müll. Arg.

Specimen examined: POLAND. Malopolska Province, N of Markowe Szczawiny shelter house, fs no. $73 \mathrm{~b}\left[49^{\circ} 35^{\prime} 49.3^{\prime \prime} \mathrm{N} / 19^{\circ} 31^{\prime} 13.1^{\prime \prime} \mathrm{E}\right]$, alt. $880 \mathrm{~m}$, on sandstone pebble under root system of fallen Picea abies within Carpathian beech forest, 2.7.2009, leg. P. Czarnota 6125 (GPN).

\section{Porpidia soredizodes (Lamy) J.R. Laundon}

Specimens examined: POLAND. MaŁopolska Province, N slope of Diablak Mt., fs no. 22a [49 $\left.34^{\prime} 54^{\prime \prime} \mathrm{N} / 19^{\circ} 31^{\prime} 39.9^{\prime \prime} \mathrm{E}\right]$, alt. $1220 \mathrm{~m}, 7.8 .2009$, leg. P. Czarnota 6250 (GPN); ibid., [49 $34^{\prime} 36.6^{\prime \prime} \mathrm{N} / 19^{\circ} 31^{\prime} 23.00^{\prime \prime} \mathrm{E}$ ], alt. $1370 \mathrm{~m}, 21.6 .2009$, leg. M. Węgrzyn 3323 (KRA); ibid., fs no. $10 \mathrm{~g}\left[49^{\circ} 34^{\prime} 56.7^{\prime \prime} \mathrm{N} / 19^{\circ} 31^{\prime} 54.8^{\prime \prime} \mathrm{E}\right]$, alt. $1170 \mathrm{~m}, 3.7 .2009$, leg. P. Czarnota $6145(\mathrm{GPN})$.

Ecology \& Distribution: This saxicolous species is frequent in the Polish Western Carpathians on various acidic rocks (Jabłońska 2010). However, since it resembles Porpidia tuberculosa (Sm.) Hertel \& Knoph, also abundant there, correct determination of both species requires analyses of their secondary compounds. In the Babia Góra Massif, $P$. soredizodes has been found on sandstone rocks in forested zones.

\section{Psilolechia clavulifera (Nyl.) Coppins}

Specimens examined (selected): POlAnd. Mazopolska Province, N slope of Diablak Mt., fs no. 22a [49 $\left.34^{\prime} 46.4^{\prime \prime} \mathrm{N} / 1^{\circ} 31^{\prime} 34.3^{\prime \prime} \mathrm{E}\right]$, alt. $1300 \mathrm{~m}, 7.8 .2009$, leg. P. Czarnota 6275 (GPN); N slope of Sokolica hill, fs no. 7a [49 $\left.35^{\prime} 27.1^{\prime \prime} \mathrm{N} / 19^{\circ} 33^{\prime} 28.5^{\prime \prime} \mathrm{E}\right]$, alt. 1090 m, 21.7.2009, leg. P. Czarnota 6248 (GPN); E slope of Sokolica hill, fs no. 25a [49 $35^{\prime} 09.5^{\prime \prime} \mathrm{N} / 19^{\circ} 34^{\prime} 05.8^{\prime \prime} \mathrm{E}$ ], alt. $1280 \mathrm{~m}, 9.6 .2009$, leg. P. Czarnota 6029 (GPN); SE

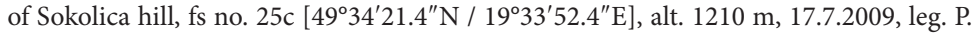
Czarnota 6216 (GPN); ibid., [49³4'51.7"N / 19³4'06.5"E], alt. 1300 m, 24.5.2009, leg. M. Węgrzyn 3183 (KRA).

ECOlogy \& Distribution: Recently Czarnota \& Kukwa (2008b) presented a modern distribution of $P$. clavulifera in Poland that shows the best habitats as being roots, soil, and acidic rocks under root systems of wind-throws. The same is also observed in the Babia Góra Massif, confirming the species as an early colonizer of such habitats.

\section{Pycnora praestabilis (Nyl.) Hafellner}

In Central Europe, $P$. praestabilis is reported as a separate species resembling the Scandinavian P. xanthococca; however the phenetic characters are not so distinct. In the Western Carpathians, P. praestabilis very frequently grows in association with $P$. sorophora, which is sorediate and usually sterile but chemically similar. Some morphs of both species seem to be transient and the small conidial size differences regarded as diagnostic (Timdal 1984) are not necessarily convincing in identification. Moreover, pycnidia are not always present in P. sorophora; thus, separation of the species will probably rely on future molecular evidence. Here, $P$. praestabilis is recognized only as a fertile, non-sorediate Pycnora morphotype. 
Specimens examined (selected): POland. Malopolska Province, N slope of Diablak Mt., fs no. 22a [49 $\left.34^{\prime} 44.5^{\prime \prime} \mathrm{N} / 1^{\circ} 31^{\prime} 32.2^{\prime \prime} \mathrm{E}\right]$, alt. $1335 \mathrm{~m}, 7.8 .2009$, leg. P. Czarnota 6256 (GPN); below Brona Pass, fs no. 24a [49³5'10.1"N / 19³0'47.2"E], alt. $1240 \mathrm{~m}, 14.7 .2009$, leg. P. Czarnota 6178 (GPN); S of Sokolica hill, fs no. 25c [49 $34^{\prime} 58.2^{\prime \prime} \mathrm{N} / 19^{\circ} 33^{\prime} 48.6^{\prime \prime} \mathrm{E}$ ], alt. $1285 \mathrm{~m}, 1.7 .2009$, leg. P. Czarnota 6110 (GPN); SE slope of Gówniak hill, fs no. $27 \mathrm{f}\left[49^{\circ} 34^{\prime} 4.2^{\prime \prime} \mathrm{N} / 19^{\circ} 33^{\prime} 02.1^{\prime \prime} \mathrm{E}\right]$, alt. $1350 \mathrm{~m}, 28.5 .2009$, leg. M. Węgrzyn 3362 (KRA).

Ecology \& Distribution: In the Babia Góra Massif, P. praestabilis frequently occurs on wood of decorticated Picea abies trunks, but mostly within well-lit upper montane spruce forest destroyed by the activity of the bark beetle Ips typographus.

\section{Pycnora sorophora (Vain.) Hafellner}

Specimens examined (selected): POLAND. Malopolska Province, N slope of Diablak Mt., fs no. 23a [49 $\left.34^{\prime} 44.6^{\prime \prime} \mathrm{N} / 1^{\circ} 31^{\prime} 17.6^{\prime \prime} \mathrm{E}\right]$, alt. $1330 \mathrm{~m}, 7.8 .2009$, leg. P. Czarnota 6269 (GPN); N slope of Sokolica hill, fs no. $7 \mathrm{a}\left[49^{\circ} 35^{\prime} 22.6^{\prime \prime} \mathrm{N} / 19^{\circ} 33^{\prime} 07.5^{\prime \prime} \mathrm{E}\right.$ ], alt. $1080 \mathrm{~m}, 25.8 .2009$, leg. P. Czarnota 6331 (GPN); below Brona Pass, fs no. 24a [49 $\left.35^{\prime} 10.1^{\prime \prime} \mathrm{N} / 19^{\circ} 30^{\prime} 47.2^{\prime \prime} \mathrm{E}\right]$, alt. $1240 \mathrm{~m}, 14.7 .2009$, leg. P. Czarnota 6179 (GPN); S of Sokolica hill, fs no. 25c [49 $\left.34^{\prime} 58.2^{\prime \prime} \mathrm{N} / 1^{\circ} 33^{\prime} 48.6^{\prime \prime} \mathrm{E}\right]$, alt. $1285 \mathrm{~m}, 1.7 .2009$, leg. P.

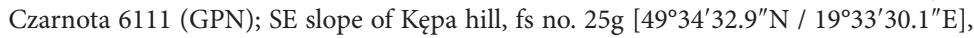
alt. 1440 m, 18.9.2010, leg. M. Węgrzyn 4212 (KRA).

ECOlogy \& Distribution: In the Babia Góra Massif, P. sorophora is more frequent than P. praestabilis, occupying similar woody habitats, as well as the bark of Norway spruces, but is not strictly confined to upper montane stands (see above).

\section{Strangospora moriformis (Ach.) Stein}

Specimens examined (selected): POLAND. Malopolska Province, E slope of Sokolica hill, fs no. $25 \mathrm{a}\left[49^{\circ} 35^{\prime} 02.8^{\prime \prime} \mathrm{N} / 1^{\circ} 34^{\prime} 05.6^{\prime \prime} \mathrm{E}\right]$, alt. $1220 \mathrm{~m}, 1.7 .2009$, leg. P. Czarnota 6112 (GPN); ibid., [49³5'09.6"N / 19³4'08.6"E], alt. $1265 \mathrm{~m}, 9.6 .2009$, leg. P. Czarnota 5989 (GPN); below Brona Pass, fs no. 24a [49 35'10.5"N / 19³0'47.4"E], alt. 1240 m, 14.7.2009, leg. P. Czarnota 6191 (GPN); N slope of Diablak Mt., fs no. 22a [49 $34^{\prime} 48.2^{\prime \prime} \mathrm{N} / 19^{\circ} 31^{\prime} 34.1^{\prime \prime} \mathrm{E}$ ], alt. $1270 \mathrm{~m}, 7.8 .2009$, leg. P. Czarnota 6260 (GPN); E of Markowe Szczawiny shelter house, fs no. $10 \mathrm{~d}\left[49^{\circ} 35^{\prime} 26.0^{\prime \prime} \mathrm{N} / 19^{\circ} 29^{\prime} 44.5^{\prime \prime} \mathrm{E}\right]$, alt. $1105 \mathrm{~m}$, 4.9.2010, leg. M. Węgrzyn 4154 (KRA).

ECOLOGY \& DISTRIBUTION: Strangospora moriformis was formerly rarely reported from Western Carpathians, including the Tatra Mts (Bielczyk 2003, Lisická 2005), but recent investigations show that this species is common in dead (destroyed by the bark beetle) parts of upper montane spruce forests throughout the Polish Western Beskidy Mts (Czarnota unpubl.). It is an early colonizer of such natural woody substrates associated, for example, with Mycocalicium subtile, Lecanora subintricata, and Lecidea turgidula. It is interesting that this species has not been found in similar habitats in the Polish Tatra Mts, despite recent intensive field explorations.

\section{Trapelia corticola Coppins \& P. James}

Specimens examined (selected): POLAND. Matopolska Province, N slope of Sokolica hill, fs no. $18 \mathrm{~b}\left[49^{\circ} 35^{\prime} 21.5^{\prime \prime} \mathrm{N} / 1^{\circ} 33^{\prime} 39.1^{\prime \prime} \mathrm{E}\right]$, alt. $1120 \mathrm{~m}, 10.6 .2009$, leg. P. Czarnota 6006 (GPN); N of Markowe Szczawiny shelter house, fs no. $74 \mathrm{~b}$ [49 $39^{\circ} 48^{\prime \prime} \mathrm{N}$ / 19³1'12.4"E], alt. 890 m, 2.7.2009, leg. P. Czarnota 6129 (GPN); SE slope of Sokolica hill, fs no. 25c, [493' $51.7^{\prime \prime} \mathrm{N} / 19^{\circ} 34^{\prime} 06.5^{\prime \prime} \mathrm{E}$ ], alt. $1300 \mathrm{~m}, 24.5 .2009$, leg. M. Węgrzyn 3171 (KRA). 
ECOlogy \& Distribution: A modern distribution of this sterile, sorediate species in Poland is presented by Czarnota \& Kukwa (2009); based on this and recent field data, T. corticola seems to be common throughout the Western Carpathians (Czarnota unpubl.) but is usually found in ancient or natural forest communities with abundant standing or fallen 'dead wood'.

\section{Trapelia obtegens (Th. Fr.) Hertel}

Specimens examined: POLAND. Matopolska Province, S of Sokolica hill, fs no. $25 \mathrm{c}\left[49^{\circ} 35^{\prime} 01.9^{\prime \prime} \mathrm{N} / 19^{\circ} 33^{\prime} 55.8^{\prime \prime} \mathrm{E}\right]$, alt. $1260 \mathrm{~m}, 1.7 .2009$, leg. P. Czarnota 6089 (GPN); ibid., [49 $34^{\prime} 51.7^{\prime \prime} \mathrm{N} / 19^{\circ} 34^{\prime} 06.5^{\prime \prime} \mathrm{E}$ ], alt. $1300 \mathrm{~m}, 24.5 .2009$, leg. M. Węgrzyn 3178 (KRA); SE slope of Kępa hill, fs no. 25c, [49³4'48.0"N / 19³4'06.8"E], alt. 1290 m, 16.9.2009, leg. P. Czarnota 6352 (GPN).

ECOLOGY \& DISTRIBUTION: This epilithic early colonizer is usually found on acidic rocks in well-lit places. In forested parts of the Western Carpathians, including the Babia Góra Massif, T. obtegens is mostly confined to small sandstone pebbles lying on root systems of wind-throws.

Trapeliopsis glaucolepidea (Nyl.) Gotth. Schneid.

Plate $1 \mathrm{H}$

This species is recognized under two different morphotypes: (1) as T. glaucolepidea forming more or less distinct squamules with lip-shaped soralia and (2) as T. percrenata (Nyl.) Gotth. Schneid. producing punctiform soralia at a very early thallus developmental stage and thus never distinctly squamulose. Recent ITS analyses (Palice \& Printzen 2004) support previous assumptions that both morphotypes could be conspecific (Palice 1999). In tropical populations T. glaucolepidea was found to be usually squamulose and often fertile but in Europe both phenetic forms are found and are almost exclusively sterile (Palice \& Printzen 2004). It is interesting that European squamulose forms occur in regions with high precipitation (western Europe and mountains in the Central Europe) growing on a strongly decayed wood or humus, while the 'T.percrenata' morphotypes occur on somewhat harder wood or are sometimes epiphytic and much more widespread in European lowlands.

The small, almost only sorediate stage of the species mostly resembles Trapelia corticola, another lichen found in similar habitats throughout Europe. The two morphologically similar species are composed of separate, punctiform, bright green to whitish-green soralia but differ in their chemistry. Trapelia corticola produces gyrophoric acid, which can be detected in the simple spot test reaction $\mathrm{C}+\mathrm{red}$, while Trapeliopsis glaucolepidea soralia are $\mathrm{C}-$. There are also 'soraliate' epixylic Micarea prasina forms that may resemble the punctiform T. glaucolepidea morphotypes (Czarnota unpubl.). In such cases, both species can be also identified based on their chemistry, although the micareic acid present in $M$. prasina is only detected by chromatography. The squamulose forms of T. glaucolepidea are very similar to the young thalli of many Cladonia taxa that often grow together in the same place. Here the presence of lip-shape soralia diagnoses $T$. glaucolepidea. 
Specimens examined: POLAND. MaŁopolska Province, N slope of Diablak Mt., fs no. $23 \mathrm{~b}\left[49^{\circ} 34^{\prime} 57.6^{\prime \prime} \mathrm{N} / 1^{\circ} 31^{\prime} 13.2^{\prime \prime} \mathrm{E}\right]$, alt. $1265 \mathrm{~m}, 7.8 .2009$, leg. P. Czarnota 6278

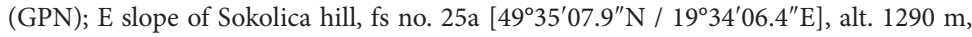
9.6.2009, leg. P. Czarnota 6012 (GPN).

Ecology \& Distribution: On the Polish side of the Carpathians, T. glaucolepidea has been reported only four times from the neighbouring Gorce Mts and Tatra Mts (Czarnota \& Kukwa 2004; Czarnota 2010), but it is a widespread species, known also from the Slovak and Ukrainian Carpathians (Palice \& Printzen 2004; Palice et al. 2006; Vondrák et al. 2010). In the Babia Góra Massif, it is found on humus and strongly decayed wood over root systems of up-ended spruces in natural upper montane spruce stands. Only the squamulose morphotype has been observed there and in the Tatra Mts, whereas the ' $T$. percrenata' form dominates in the Gorce Mts. In the first two ranges T. glaucolepidea has been recorded above $1200 \mathrm{~m}$ a.s.l., while in Gorce Mts its localities do not exceed $1020 \mathrm{~m}$.

\section{Trapeliopsis pseudogranulosa Coppins \& P. James}

Specimens examined (selected): POLAND. Malopolska Province, N slope of Sokolica hill, fs no. 6d [49 $\left.35^{\prime} 27.7^{\prime \prime} \mathrm{N} / 19^{\circ} 33^{\prime} 42.5^{\prime \prime} \mathrm{E}\right]$, alt. $1060 \mathrm{~m}, 25.8 .2009$, leg. P. Czarnota 6294 (GPN); ibid., fs no. 7a $\left[49^{\circ} 35^{\prime} 24.3^{\prime \prime} \mathrm{N} / 19^{\circ} 33^{\prime} 12.7^{\prime \prime} \mathrm{E}\right]$, alt. $1060 \mathrm{~m}$, 21.7.2009, leg. P. Czarnota 6228 (GPN); N of Markowe Szczawiny shelter house, fs no. $73 \mathrm{~b}\left[49^{\circ} 35^{\prime} 49.3^{\prime \prime} \mathrm{N} / 19^{\circ} 31^{\prime} 13.1^{\prime \prime} \mathrm{E}\right]$, alt. $880 \mathrm{~m}, 2.7 .2009$, leg. P. Czarnota 6127 (GPN).

Ecology \& Distribution: A common species throughout the Carpathians, being mostly found in the Babia Góra Massif on decaying wood of wind-throws in shady and moist forests.

\section{Acknowledgements}

We would like to thank Józef Omylak (Director of the Babia Góra National Park) for permission to research lichen biota in the National Park area and Tomasz Lamorski for help in conducting fieldwork and invaluable advice. We are also grateful to Dr Piotr Osyczka (Kraków) for his assistance in determining some Cladonia and Lepraria species by TLC, to Natalia Gucwa for tireless assistance in the field and the herbarium, and to Prof. Mark Seaward (Bradford, UK) for linguistic corrections and valuable improvements. We are greatly indebted also to Dr Anna Guttova (Slovakia, Bratislava) and Dr Vagn Alstrup (Denmark, Copenhagen) for valuable criticism of the manuscript. This research was supported by the Polish Ministry of Science and Higher Education, grants No. N N305 306835 (P. Czarnota) and N N305 277933 (M. Węgrzyn).

\section{Literature cited}

Ahti T. 2000. Cladoniaceae. Flora Neotropica Monograph 78: 1-362.

Andersen HL, Ekman S. 2005. Disintegration of the Micareaceae (lichenized Ascomycota): a molecular phylogeny based on mitochondrial rDNA sequences. Mycological Research 109(1): 21-30. http://dx.doi.org/10.1017/S0953756204001625

Aptroot A, Gilbert OL, Hawksworth DL, Coppins BJ. 2009. Lecidea Ach. (1803). 502-519, in: CW Smith et al. (eds), The Lichens of Great Britain and Ireland. British Lichen Society, London..

Bayerová Š, Kukwa M, Fehrer J. 2005. A new species of Lepraria (lichenized ascomycetes) from Europe. Bryologist 108: 131-138.

http://dx.doi.org/10.1639/0007-2745(2005)108[131:ANSOLL]2.0.CO;2

Bielczyk U. 2003. The lichens and allied fungi of the Polish Western Carpathians. 23-232, in: U Bielczyk (ed.), The lichens and allied fungi of the Polish Carpathians - an annotated checklist, 
Biodiversity of the Polish Carpathians. W. Szafer Institute of Botany, Polish Academy of Sciences, Kraków.

Bielczyk U. 2004. Różnorodność gatunkowa porostów Babiogórskiego Parku Narodowego. 285-314, in: BW Wołoszyn et al. (eds), Babiogórski Park Narodowy. Monografia przyrodnicza, Wydawnictwo i Drukarnia Towarzystwa Słowaków w Polsce, Kraków.

Boberski W. 1886. Systematische Übersicht der Flechten Galiziens. Verh. Zool.-Bot. Ges. Wien 36: 243-286.

Bylin A, Arnerup J, Högberg N, Thor G. 2007. A phylogenetic study of Fuscideaceae using mtSSU rDNA. Bibliotheca Lichenologica 96: 49-60.

Coppins BJ. 1983. A taxonomic study of the lichen genus Micarea in Europe. Bull. Brit. Mus. Nat. Hist. 11: 17-214.

Coppins BJ. 2009. Micarea Fr. (1825). 583-686, in: CW Smith et al. (eds), The Lichens of Great Britain and Ireland. British Lichen Society, London..

Coppins BJ, Kondratyuk S, Khodosovtsev A, Zelenko S, Coppins A, Wolseley P, Virchenko V. 1998. Diversity of lichens and bryophytes in Regional Landscape Park 'Stuzhytsia' (Ukrainian part of the international biosphere reserve 'Eastern Carpathians'). 139-161, in: S Kondratyuk, BJ Coppins (eds), Lobarion lichens as indicators of the primeval forests of the Eastern Carpathians, Darwin International Workshop, 25-30 May 1998, Kostrino. Phytosociocentre, Kiev.

Coppins BJ, Kondratyuk SYa, Khodosovtsev AYe, Zelenko SD, Wolseley PA. 2005. Contribution to lichen flora of Ukrainian Carpathians. Chornomors'ki Bot. J. 1: 5-23.

Czarnota P. 1997. Micarea synotheoides, M. hedlundi (Micareaceae) and Leptogium intermedium (Collemataceae), three lichens new to Poland. Fragm. Flor. Geobot. 42(2): 489-494.

Czarnota P. 2003. Notes on some new and noteworthy lichens from southern Poland. Graphis Scripta 14: 18-26.

Czarnota P. 2007. The lichen genus Micarea (Lecanorales, Ascomycota) in Poland. Polish Bot. Stud. 23: 1-199.

Czarnota P. 2010. Krytyczna lista porostów i grzybów naporostowych Gorców. Ochrona Beskidów Zachodnich 3: 55-78.

Czarnota P, Guzow-Krzemińska B. 2010. A phylogenetic study of the Micarea prasina-group shows that Micarea micrococca includes three distinct lineages. Lichenologist 42: 7-20. http://dx.doi.org/10.1017/S0024282909990211

Czarnota P, Kukwa M. 2001. Lichens of the genera Lepraria and Leproloma from the Gorce Mts (Western Carpathians, Poland) and note on lichenicolous fungus Paranectria oropensis found on Leproloma membranaceum. Polish Bot. J. 46: 199-206.

Czarnota P, Kukwa M. 2004. Some sorediate lichens and lichenicolous fungi new to Poland. Graphis Scripta 15: 24-32.

Czarnota P, Kukwa M. 2008a. Contribution to the knowledge of some poorly known lichens in Poland. I. The genus Absconditella. Folia Cryptog. Estonica 44: 1-7.

Czarnota P, Kukwa M. 2008b. Contribution to the knowledge of some poorly known lichens in Poland. II. The genus Psilolechia. Folia Cryptog. Estonica 44: 9-15.

Czarnota P, Kukwa M. 2009. Contribution to the knowledge of some poorly known lichens in Poland. III. Trapelia corticola and the genus Vezdaea. Folia Cryptog. Estonica 46: 25-31.

Edwards B, Aptroot A, Hawksworth DL, James PW. 2009. Lecanora Ach. in Luyken (1809). 465-502, in: CW Smith et al. (eds), The Lichens of Great Britain and Ireland. British Lichen Society, London.

Fałtynowicz W. 2003. The lichens, lichenicolous and allied fungi of Poland. An annotated checklist. Biodiversity of Poland 6. W. Szafer Institute of Botany, Polish Academy of Sciences, Kraków. $435 \mathrm{p}$.

Fletcher A, Coppins BJ. 2009. Catillaria A. Massal. (1852). 282-288, in: CW Smith et al. (eds), The Lichens of Great Britain and Ireland. British Lichen Society, London.

Giavarini V, Coppins BJ. 2009. Chaenothecopsis Vain. (1927). 303-307, in: CW Smith et al. (eds), The Lichens of Great Britain and Ireland. British Lichen Society, London. 
Gilbert OL, Jørgensen PM. 2009. Leptogium (Ach.) Gray (1821). 541-551, in: CW Smith et al. (eds), The Lichens of Great Britain and Ireland. British Lichen Society, London.

Gilbert OL, Purvis OW, Skjoldahl LH, Tønsberg T. 2009. Fuscidea V. Wirth \& Vězda (1972). 407-411, in: CW Smith et al. (eds), The Lichens of Great Britain and Ireland. British Lichen Society, London.

Golubkov VV, Kukwa M. 2006. A contribution to the lichen biota of Belarus. Acta Mycol. 41: 155-164.

Guttová A. 2001 Zaujímavejšie floristické nálezy. Bull. Slov. Bot. Spoločn. 23: 1-208.

Jabłońska A. 2010. The lichen genus Porpidia in Poland III. Herzogia 23: 217-228.

James PW. 2009. Cladonia P. Browne (1756). 309-338, in: CW Smith et al. (eds), The Lichens of Great Britain and Ireland. British Lichen Society, London.

Jørgensen PM. 1994. Further notes on European taxa of the lichen genus Leptogium, with emphasis on the small species. Lichenologist 26: 1-29.

Kiszka J. 1967. Porosty Beskidu Śląskiego. Rocznik Naukowo-Dydaktyczny WSP w Krakowie, Prace z botaniki 28: 5-91.

Kiszka J, Kościelniak R. 1998. The flora of lichens in the Polish Eastern Carpathians. 82-101, in: S Kondratyuk, BJ Coppins (eds), Lobarion lichens as indicators of the primeval forests of the Eastern Carpathians, Darwin International Workshop, 25-30 May 1998, Kostrino. Phytosociocentre, Kiev.

Kondratyuk SYa, Coppins BJ. 2000. Basement for the lichen monitoring in Uzhansky National Nature Park, Ukrainian Part of the Biosphere Reserve 'Eastern Carpathians'. Roczniki Bieszczadzkie 8: 149-192.

Kościelniak R, Kiszka J. 2003. The lichens and allied fungi of the Polish Eastern Carpathians. 233-294, in: U Bielczyk (ed.), The lichens and allied fungi of the Polish Carpathians - an annotated checklist, Biodiversity of the Polish Carpathians. W. Szafer Institute of Botany, Polish Academy of Sciences, Kraków.

Kossowska M. 2008. Lichens growing on calcareous rocks in the Polish part of the Sudety Mountains. Acta Bot. Siles. Monogr. 3: 1-110.

Kukwa M. 2004. Porosty z rodzaju Lepraria w Tatrzańskim Parku Narodowym. Parki nar. Rez. Przyr. 23: 3-12.

Kukwa M. 2006. The lichen genus Lepraria in Poland. Lichenologist 38: 293-305. http://dx.doi.org/10.1017/S0024282906005962

Kukwa M, Sliwa L. 2005. The genus Lepraria (lichenized Ascomycota) in the Beskid Sądecki Mts (West Carpathians, S Poland). Polish Bot. J. 50: 163-184.

Kukwa M, Szymczyk R. 2006. Stanowiska porostu Mycobilimbia epixanthoides (Ascomycota lichenisati) na północy Polski. Fragm. Flor. Geobot. Ser. Polonica 13: 429-432.

Kukwa M, Czarnota P, Perz P. 2010. New or interesting records of lichenicolous fungi from Poland VIII. Herzogia 23: 111-119.

Lendemer J.C. 2011. A review of the morphologically similar species Fuscidea pusilla and Ropalospora viridis in eastern North America. Opuscula Philolichenum 9: 11-20.

Lisická E. 1980. Flechtenfamiie Umbilicariaceae Fée in der Tschechoslowakei. Biol. Práce Slov. Akad. Vied 26: 1-151.

Lisická E. 2005. The lichens of the Tatry Mountains. VEDA, Slovak Academy of Sciences, Bratislava. $439 \mathrm{p}$.

Malíček J, Palice Z, Kocourková J, Müller A. 2010. Contribution to the lichen flora of the Beskydy Protected Lanscape Area. Bryonora 46: 56-66.

Meyer B, Printzen C. 2000. Proposal for a standardized nomenclature and characterization of insoluble lichen pigments. Lichenologist 32: 571-583.

http://dx.doi.org/10.1006/lich.2000.0294

Nowak J. 1998. Porosty Beskidów Wyspowego i Żywieckiego, Pasma Jałowca i Masywu Babiej Góry. Monogr. Bot. 83: 55-131.

Nowak J, Tobolewski Z. 1975. Porosty polskie. PWN, Warszawa-Kraków. 1177 p. 
Orange A, James PW, White FJ. 2001. Microchemical Methods for the Identification of Lichens. British Lichen Society, London. 101 p.

Osyczka P. 2011. The genus Cladonia, group Cocciferae, in Poland. Herzogia 24: 209-227.

Osyczka P, Węgrzyn M. 2005. Arktyczno-alpejski gatunek porostu Cladonia amaurocraea w Tatrach [An arctic-alpine lichen species Cladonia amaurocraea in the Tatra Mts.]. Fragm. Flor. Geobot. Ser. Polonica 12: 157-163.

Palice Z. 1999. New and noteworthy records of lichens in the Czech Republic. Preslia 71: 289-336.

Palice Z, Printzen C. 2004. Genetic variability in tropical and temperate populations of Trapeliopsis glaucolepidea: Evidence against long-range dispersal in a lichen with disjunct distribution. Mycotaxon 90: 43-54.

Palice Z, Guttova A, Halda JP. 2006. Lichens new for Slovakia collected in the National Park Muranska planina (W Carpathians). 179-192, in: A Lackovičová et al. (eds.), Central European lichens - diversity and threat. Mycotaxon Ltd., Ithaca.

Pišút I, Lackovičová A, Guttová A, Palice Z. 2007. New lichen records from Bukovské vrchy Mts (NE Slovakia). Acta Mycol. 42: 267-280.

Printzen C, Palice Z. 1999. The distribution, ecology and conservational status of the lichen genus Biatora in central Europe. Lichenologist 31: 319-333.

Rehman A. 1879. Systematyczny przegląd porostów znalezionych dotąd w Galicji Zachodniej opracowany na podstawie własnych i cudzych spostrzeżeń. Spraw. Komisji Fizjogr. PAU 13: $3-66$.

Sérusiaux E, Brand AM, Motiejunaite J, Orange A, Coppins BJ. 2010. Lecidea dolliformis belongs to Micarea, Catillaria alba to Biatora, and Biatora ligni-mollis occurs in Western Europe. Bryologist 113: 333-344. http://dx.doi.org/10.1639/0007-2745-113.2.333

Stein B. 1872. Flechten der Babia Góra. Verhandl. des bot. Vereins f. Brand. 14: 94-97.

Stein B. 1873. Über zwei in diesem Jahre von ihm botanische Excursionennach der Babia Gora. Jahresber. Schles. Ges. Vaterl. Cult. 50: 119-123.

Suza J. 1951. Lišejníky Babia Gory a vrchovišt’ v přilehlé Oravské pánvi (slovenské části). Lichens de Babia Gora et des tourbières du bassin voisin de Orava (Slovaquie). Sborník Klubu př́rodovědeckého v Brně 29: 147-156.

Svensson M, Westberg M. 2010. Additions to the lichen flora of Fennoscandia. Graphis Scripta 22: 33-37.

Timdal E. 1984. The genus Hypocenomyce (Lecanorales, Lecideaceae), with special emphasis on the Norwegian and Swedish species. Nordic J. Bot. 4: 83-10.

http://dx.doi.org/10.1111/j.1756-1051.1984.tb01979.x

Tobolewski Z. 1966. Rodzina Caliciaceae (Lichenes) w Polsce. Poznańskie Towarzystwo Przyjaciół Nauk, Wydział Matematyczno-Przyrodniczy. Prace Komisji Biologicznej 24 (5): 1-106.

Tønsberg T. 1992. The sorediate and isidiate, corticolous, crustose lichens in Norway. Sommerfeltia 14: $1-331$.

Vondrák J, Palice Z, Khodosovtsev A, Postoyalkin S. 2010. Additions to the diversity of rare or overlooked lichens and lichenicolous fungi in Ukrainian Carpathians. Chornomors'ki Bot. J. 6: 6-34.

Vězda A. 1993. Lichenes Rariores Exsiccati. Fasc. 6. Brno.

Węgrzyn M. 2002. Nowe stanowiska Fellhanera subtilis na południu Polski. Fragm. Flor. Geobot. Ser. Polonica. 9: 388-389.

Węgrzyn M. 2004. Porosty epifityczne, epiksyliczne i epigeiczne piętra kosodrzewiny na Babiej Górze. Fragm. Flor. Geobot. Ser. Polonica 11:355-363. 